\title{
Derek Mahon's Nerval
}

\section{Author(s): Kathleen Shields}

Source: Translation and Literature, Vol. 4, No. 1 (1995), pp. 61-74

Published by: Edinburgh University Press

Stable URL: https://www.jstor.org/stable/40339696

Accessed: 22-08-2019 13:38 UTC

JSTOR is a not-for-profit service that helps scholars, researchers, and students discover, use, and build upon a wide range of content in a trusted digital archive. We use information technology and tools to increase productivity and facilitate new forms of scholarship. For more information about JSTOR, please contact support@jstor.org.

Your use of the JSTOR archive indicates your acceptance of the Terms \& Conditions of Use, available at https://about.jstor.org/terms 


\title{
Derek Mahon's Nerval
}

\author{
Kathleen Shields
}

The Northern Irish poet Derek Mahon published in 1982 a version of Gérard de Nerval's sonnet sequence Les Chimères, Nerval's best-known work both inside and outside France. ${ }^{1}$ In the English-speaking world there is a tradition of translating this sequence which began with the symbolist poet Arthur Symons. ${ }^{2}$ In this tradition Nerval is presented as a strange bohemian, a 'fol délicieux', or as a type of poète maudit. ${ }^{3}$ Mahon's text does not allude in any way to this tradition, or to the quotation of Nerval by English-language poets like Eliot in The Waste Land. Instead it appears as a fresh translation aimed at a public unfamiliar with Nerval. But there is another tradition which Mahon's Irish public would recognize, and this is the wealth of translations and 'versions' which Irish poets publish as part of the body of their work.

In twentieth-century Irish poetry the production of translations is extraordinarily prevalent. There are two reasons for this. First, there are those writers who could be described as modernists who translated from European literatures in the I930s and whose aim was to free Irish writing from the imprint of cultural nationalism left on it by Yeats. The translations of Samuel Beckett, Brian Coffey, and Denis Devlin can be considered in this light. In an attack on the legacy of Yeats, Beckett wrote in I934 that 'contemporary Irish poets may be divided into antiquarians and others, the former in the majority, the latter kindly noticed by Mr. W. B. Yeats as "the fish that lie gasping on the shore". ${ }_{4}$ Coffey and Devlin, whose poetry reflects the influence of Corbière, Rimbaud, Laforgue, and the surrealists, constitute, according to Beckett, 'the nucleus of a living poetic in Ireland'. These poets were more than influenced by the other literatures of Europe - through their translations they were in fact mediators, opening up an Irish literature which had become too inward-looking. ${ }^{5}$ Mahon, in translating from French, is similarly motivated. He himself echoes Beckett's analysis in his description of the followers of Yeats:

[Their] assumptions and credulities were those of the Irish country people of the time, and the Irish, for many years, returned the 
poets' reverence with reverence for a poetry which evaded the metaphysical unease in which all poetry of lasting value has its source. $^{6}$

In a culture which has grown too ethnocentric, translation, an encounter with another culture, can become a way of expressing the poet's metaphysical unease.

The second category of translations by Irish poets writing in English consists of those done from the Irish language. According to the poet Thomas Kinsella, such work is often undertaken as a 'labour of some kind of love', to heal the rift caused by the great silence of the nineteenth century. ${ }^{7}$ The motive behind them appears as a search for an Irish cultural identity. Translation in these cases is not an antiquarian activity, then: it is a necessity if the collective trauma of the loss of a language is to be overcome.

The period from the r 970 saw a growth in the number of translations generally. Seamus Heaney translates Dante, Thomas Kinsella translates An Táin Bó Cuailnge, Derek Mahon translates Rimbaud and Jaccottet, John Montague translates Frénaud, Michael Hartnett translates Nuala Ní Dhomhnaill, Paul Muldoon translates Michael Davitt. Why so many, whether from Irish or from other European languages? From the beginning of the 1970 s the Troubles in Northern Ireland raise the problem of cultural nationalism as ethnocentrism. There is a need on the one hand for self-definition or self-redefinition (hence the translations from Irish), and on the other hand a need to write about the Irish situation on a wider stage, to comment on it and to seek relief from it, through the prism of another culture. In the recent work of Ciaran Carson there is a coming together of the two motives. ${ }^{8}$ Irish literary culture has a place among the cultures of Europe, and perhaps a pluralist literature is a harbinger of a pluralist society.

The reader hoping to find in Mahon's Chimeras an introduction to the poetry of Nerval might be disappointed. If the fundamental duty of a translator is to transfer meaning from the source-language text to a target-language text, then Mahon is shirking his responsibilities. At times he ignores the systemic differences between the English and French languages, or emphasizes them too much. At other times he does not recognize the special use which Nerval makes of features of French. We could read these as tics or mannerisms on Mahon's part, or we could more fruitfully ask why he adopts certain strategies, even if these strategies appear unnecessary from the translator's point of view. There are parallels between the way he translates and the way he writes the rest of 
his poetry which can provide an explanation of what he is doing in translating Nerval.

In many ways Mahon's sequence The Chimeras is, to borrow Eugene Nida's expression, a dynamic equivalent translation, that is to say, it is oriented towards the target-language audience and not towards the source-language text. ${ }^{9}$ Or, to adopt the terminology of a more recent writer on translation theory, Lawrence Venuti, it could be said that Mahon follows many English-speaking translators in minimizing the cultural strangeness of the other text by adapting it to suit targetlanguage expectations. ${ }^{10}$ In certain respects Mahon's text could be seen as an example of the English-language translation which tames and appropriates other cultures. It is true that he diminishes the richness and density of Nerval's sonnets and simplifies many of the cultural references. This drawing of the other text to one's own cultural centre does indeed resemble what Venuti calls the 'labour of acculturation'. " But at times, even if the strangeness is not the strangeness of Nerval, Mahon makes his text seem outlandish. What is Mahon's cultural centre? And why does he need simultaneously to centre and decentre his text? ${ }^{12}$ There is something more going on in the Chimeras than the acculturation of Nerval to suit an Anglo-American readership. This is made clear by the fact that Mahon deliberately complicates the Nerval texts, adding to them after subtracting from them. It is as if he first simplifies the sourcetext of the Chimeres - rather than merely acculturating it - and then deliberately makes his translation sound alien. At times, these strategies produce bizarre translations. The new elements that Mahon brings to some of the Chimeres through translating can be linked to the fact that he is writing about Northern Ireland. He translates in order to distance himself from a culture which is too close. The question, what is the purpose of Mahon's translating, leads to some interesting conclusions about his own culture and how he relates to it in his writing.

Two contrary impulses are apparent in the Chimeras. The first is to simplify the situations in Nerval's sonnets by demythologizing them and by changing syntax and verb tenses and aspects. The second is to make the English in the translations appear strange and to give them a Gallic or a foreign patina. Before attempting to understand the reason for these two impulses it is necessary to examine them more closely.

The source-texts are much more dense and more closely wrought than their translations. The Nerval sonnets bristle with names from Greek, Egyptian, and Middle Eastern mythologies. These names are eliminated in many cases in the translations, except in the titles where the name serves to conjure the central figure in each poem. ${ }^{13} \mathrm{~A}$ striking deletion of proper nouns can be seen in Mahon's sonnet 'El Desdichado', 
where the disinherited speaker, the Aquitainian prince, undergoes an identity crisis. In the first tercet Nerval's 'Prince d'Aquitaine' asks:

Suis-je Amour ou Phoebus? ... Lusignan ou Biron? Mon front est rouge encor du baiser de la Reine; J'ai rêvé dans la Grotte où nage la Syrène ...

Mahon's prince asks instead:

I am what childe of legend or romance?

My brow burns with a queenly kiss; my dreams

Have visited the cave where the Siren swims.

The spelling of 'childe' very deftly alludes to Byron, picking up on Nerval's own variant spellings of the name, and maintaining the contrast between pre-Christian legend and medieval romance. But by eliminating the proper nouns Mahon circumvents the problem of whether Nerval's 'or's are really 'and's. Is Amour linked with Phoebus or with Lusignan? Is Phoebus linked with Amour or Biron? As for the real identity implied by these names, or the exact nature of the syntax: 'les exégèses s'accumulent et divergent, les uns optant pour l'énumération, les autres pour le chiasme'. ${ }^{14}$

To some extent this simplification of the source-text is due to the vast differences between nineteenth-century and twentieth-century readerships. Proper nouns from different mythologies could serve as a sort of shorthand for Nerval. ${ }^{15}$ Whereas Nerval can make a whole poem articulate around a series of names, Mahon's readers have a more impoverished mythological lexicon. At times Mahon translates names into approximate or less specific equivalents - thus 'Solyme' becomes 'Jerusalem', 'Jupiter Ammon' becomes 'great Jupiter', 'l'Achéron' becomes 'the Styx'. The elimination of proper nouns, due both to deliberate choice and to changing frames of reference among readerships, tends to one effect - the simplification of the source-text.

But there is another more striking way in which Mahon demythologizes Nerval, and this is through typography. The typography and punctuation of the Chimeres are bizarre, to say the least. Common nouns are given capital letters; words normally spelt with ' $i$ ' are sometimes archaized and given a ' $y$ '; some nouns are italicized as if Nerval were drawing attention to a particular arcane usage of his own. The whole effect is to make the text on the page appear as a vatic utterance. ${ }^{16}$ Nerval's use of punctuation, in particular of the comma and the dash, is also original in that the punctuation follows the speaking voice. ${ }^{17}$ 
Mahon's translations bring Nerval's Chimeres back within the norms of standard punctuation. They ignore the eccentricities of the typography and eliminate capitals, italics, and exclamation marks. Their language is ordinary, not declamatory; referential, not mythological.

There are other complexities which are smoothed out in the translations. In Nerval's sonnets the verb tenses and aspects carry an immense narrative weight. For instance, tense alone can convey contrasts such as that between linear historical time and cyclical mythological time. In Nerval's 'Myrtho' Greece represents a mythical poetical reality which existed in a time before past time, and so Nerval uses the pluperfect: 'C'est dans ta coupe aussi que j'avais bu l'ivresse.' And Mahon is right to translate this by a pluperfect in English: 'Yours was the cup where I had drunk the light.' But Mahon neglects the importance of tensedistinctions in the rest of the poem. In Nerval's poem the distant past of his experience in Greece can miraculously erupt into historical time and continue into the present. Hence the strange use of tenses in Nerval's opening lines:

Je sais pourquoi là-bas le volcan s'est rouvert... C'est qu'hier tu l'avais touché d'un pied agile, Et de cendres soudain l'horizon s'est couvert.

Strictly speaking the passé compose implies a continuing link with the present: the volcano has reopened, and the horizon has become covered with ash. The unusual pluperfect in the second of these three lines has a specific purpose. Myrtho's reawakening of the volcano is the act of a divinity and belongs to the mythological past beyond the past. Mahon translates all three verbs in this tercet by the simple past tense in English:

Why the volcano stirred again I know:

Your light feet flitted there. Abruptly, clouds

Of cindery black smoke obscured the sun.

Mahon has perhaps opted for this tense because students of French learning to translate prose texts into English are told that this tense in English can often be used to translate a French imparfait, passé composé, passé simple, and sometimes a plus-que-parfait. But normal ways of coping with systemic differences between the two languages will not help the translator of Nerval. The aspects of the verbs, such as duration, repetition, or completion, are vital to an understanding of the narrative meaning of the Chimeres. For instance, the contrast between completed action (in the passé simple) and durative, or ongoing, action (in the passé composé) 
is what structures the narration in the sonnet 'Artémis'. Mahon ignores this contrast altogether. ${ }^{18}$ These are cases where he has chosen not to translate an obligatory feature of Nerval's language with the result that temporal structures are simplified.

Simplification of syntax is another way in which Mahon smooths out the source-text, making it more fluent, but less rich. In the end-sequence of the Chimeres, 'Le Christ aux oliviers', Caesar calls on Jupiter to reveal the identity of the new god (who is Christ):

'Réponds! criait César à Jupiter Ammon, Quel est ce nouveau dieu qu'on impose à la terre? Et si ce n'est un dieu, c'est au moins un démon...'

('Le Christ aux oliviers V')

If he is not a god, then he must be a demon. This is translated as:

'Who is this new god foisted on the earth?'

Caesar demanded of great Jupiter, 'Is he a deity or a fiend? Reply!'

An element of Caesar's bewildered speculation, where he tries to fit the newcomer into his own theology, is lost here. There is a similar omission of a conjunction in the translation of 'Le Christ aux oliviers III', line 13, where the suppression of the conjunction 'car' undoes the connection between the feeling of abandonment and the absence of a god.

Another syntactic simplification is to translate the French $d e+$ noun as an adjective. This procedure can sometimes work when translating into English, but not systematically. Thus the translation loses the specific geographical meaning when 'le Prince d'Aquitaine' becomes the 'Aquitainian prince', as de here can mean both 'from' Aquitaine and 'of' Aquitaine. In the same poem the 'baiser de la Reine' is translated as 'a queenly kiss', and 'la lyre d'Orphée' translated as 'the Orphean lyre'. The de here functions as a possessive of rather than adjectivally.

The simplification of syntax, the weakening of narrative structure throughout, the omission of contrasting verb aspects, the elimination of proper nouns, mythological references, and typographical peculiarities all of these could be read as strategies which efface 'the linguistic and cultural difference of the foreign text'. ${ }^{19}$ But this description fits Mahon's strategies only up to a point. Ultimately, the act of effacing the strangeness of the foreign text also tends to be an act of self-annihilation on the part of the translator. If Mahon minimizes Nerval's strangeness and pulls the Chimeres towards the centre of his own culture, then 
opposing, decentring patterns can also be seen. Mahon does not entirely fit the mould of the self-annihilating ethnocentric translator. In one way he simplifies Nerval, but in another way he seems deliberately to make his translations strange and foreign. This strangeness, which is not Nerval's strangeness, serves as a counterweight to the simplifying strategies adopted. But, more importantly, it can be linked to a desire on Mahon's part to create a space for self-representation.

To give some examples of the strangeness of Mahon's Chimeras. First, there is the startling creation of 'French' sentence structure where the original is in fact much closer to English syntax. In Nerval's 'El Desdichado' the speaker asks: 'Suis-je Amour ou Phoebus? ... Lusignan ou Biron?' Mahon's 'El Desdichado' uses the French non-inverted question form here, where it is not even suggested by the Nerval text: 'I am what childe of legend or romance?' This is an over-Gallicization of the question form. Elsewhere it is clear that Mahon wants his readers to be aware that the text is not in any straightforward sense in contemporary English. In the sonnet 'Myrtho', for example, a common construction in French, using depuis, gives rise to an unusual one in English:

Depuis qu'un duc normand brisa tes dieux d'argile, Toujours, sous les rameaux du laurier de Virgile, Le pâle Hortensia s'unit au Myrte vert!

This becomes:

A Norman duke shattered your earthen gods Since when, beneath the Virgilian laurel-bough, Hydrangea and the green myrtle grow as one.

It could be argued that Mahon translates depuis by 'since when' because he is bound by the constraints of the sonnet form. Nevertheless, a more ordinary way of translating might be to say 'since the time' or to use the word 'since' on its own, giving a translation like, 'Since a Norman duke...'. The important thing here is that Mahon gives the translation a foreign feel, by mimicking Miltonic and Virgilian syntax. It seems that he wants his English-speaking readers to be aware that they are reading a text which has been translated out of another language.

This is clear from the very obvious transfers of meaning at the level of vocabulary. Lexical weighting compensates for the lightening of the burden of meaning carried by Nerval's syntax and verb tense and aspect. Mahon often adds in new meaning, choosing over-specific vocabulary, even where much closer synonymy exists between the two languages. To 
take just one poem, 'Le Christ aux oliviers II': les mondes becomes 'the heavens', flots argentés is translated as 'blue lagoons', le sol désert as 'deserted shores', ces immensités as 'the galaxies', and étrange as 'unexpected'. Such lexical choices are not imposed by irreconcilable differences between the two languages. Words and word-collocations which are not particularly uncommon as Nerval uses them become startling in the translation, and can provide a clue to Mahon's motives for making the translation appear strange.

One motive is the desire to quote oneself in a foreign medium. The creation of strange new adjectives from past participles is a striking and recurrent feature of Mahon's Chimeras. (For instance, a straightforward sentence in Nerval's 'Myrtho', 'Car la Muse m'a fait l'un des fils de la Grèce', is translated as: '... I fell .../ Muse-naturalized among the sons of Greece'.) But one use of this peculiar adjective-formation connects the act of making strange to the act of self-quotation. This occurs in the poem 'Antéros'. Nerval's hero, Antéros, swears to defend his mother and to avenge his ancestors for the wrongs which Jéhovah has done them:

Tu demandes pourquoi j'ai tant de rage au coeur

Et sur un col flexible une tête indomptée;

C'est que je suis issu de la race d'Antée,

Je retourne les dards contre le dieu vainqueur. [...]

Jéhovah! le dernier, vaincu par ton génie,

Qui, du fond des enfers, criait: "O tyrannie!"

C'est mon aïeul Bélus ou mon père Dagon $[\ldots]$

$\mathrm{Et}$, protégeant tout seul ma mère Amalécyte,

Je ressème à ses pieds les dents du vieux dragon.

Mahon deletes the name Amalécyte, and adds a past participial coinage of his own:

You ask me why I have a heart made mad And, on a snake's neck, a defiant face?

Sprung as I am from old Antaeus' race,

I fling the spears back at the conquering god. [...]

The last subdued by your superior power, Jehovah, screaming 'Tyrant!' from the pit, Was Baal or Dagon, father or ancestor. [...] 
Sole tutelary, the dragon-teeth I sow

Before my expropriated mother's feet.

The introduction of the word 'expropriated' is revealing. Mahon's use of it to refer to persons, and not to objects such as goods or possessions, is a direct act of self-quotation from a passage in one of his best-known poems, 'A Disused Shed in Co. Wexford'. There the reader is presented with a sequence of dissolving analogies between some mushrooms in the shed, and peoples who have been abandoned to their fate:

They [the mushrooms] have been waiting for us in a foetor

Of vegetable sweat since civil war days,

Since the gravel-crunching, interminable departure

Of the expropriated mycologist.

He never came back, and light since then

Is a keyhole rusting gently after rain.

The mycologist, who knew and understood these mushrooms, had his goods and assets seized (expropriated) by the state after the civil war. The analogy is made between the mushrooms, which 'have been so long / Expectant that there is left only the posture', and the Protestants in Ireland, abandoned by the British.

In 'Anteros' Mahon deepens his meditation on civil war. While the act of translation can distance him from the moral ambiguity he presents, it also marks the insertion-point of a classic into another historical moment, the moment where a poet attempts to dramatize the self-destructive mentality of the civil war protagonist. Using Nerval's mythical narratives gives him a certain freedom. In 'Anteros' he reverses the typical direction of the act of quotation. When we quote, we normally borrow a piece of foreign text and graft it onto our own. But Mahon grafts elements of his texts from elsewhere onto the foreign text. Within the space created by translating he can add the weight of referential detail.

An example of this process can be seen in Mahon's 'Artemis' where he substantially rewrites the Nerval text. Nerval's sonnet blends together the thirteenth hour (which is also the first hour), the goddess, and a woman once loved who is now dead:

La Treizième revient ...C'est encor la première; Et c'est toujours la Seule, - ou c'est le seul moment:

Car es-tu Reine, ô Toi! la première ou dernière? Es-tu Roi, toi le Seul ou le dernier amant? ... 
Aimez qui vous aima du berceau dans la bière;

Celle que j'aimai seul m'aime encor tendrement:

C'est la Mort - ou la Morte ...O délice! ô tourment!

La rose qu'elle tient, c'est la Rose trémière.

Because his past love is locked in cyclical time, the speaker concludes by banishing the heaven of traditional religion and by turning to his loved one in death and the abime. In Mahon's version the goddess is made to represent, not a woman once loved who is gone forever, but the pieties of provincial childhood:

Thirteen o'clock, and the first hour once more Always the only hour, the only minute.

Diana, are you finite or infinite?

Was I your only or your final lover?

The goddess carved on the provincial clock

Of childhood loves you as she always did.

Return that love for its delight and dread.

The rose she holds is the frail hollyhock.

Nerval's abime becomes the 'void' in which the provincial clock of childhood is preserved as an object of devotion. And the two additional words 'provincial' and 'childhood' can be read as self-quotations from one of Mahon's other poems, 'Courtyards in Delft'.

In 'Courtyards in Delft' a Belfast childhood is compared to the world of a seventeenth-century painting by Pieter de Hooch. The light of Delft, the light in the painting, will spread over the world like a stain:

For the pale light of that provincial town

Will spread itself, like ink or oil,

Over the not yet accurate linen

Map of the world which occupies one wall

And punish nature in the name of God. ${ }^{20}$

In 'Courtyards in Delft' the painting provides the speaker with only a certain amount of distance from his provincial childhood, as he looks on with appalled hindsight at what the Orangemen will do in Ulster or at what the Boers will do in South Africa. In 'Artemis' Mahon can less equivocally assert that the provincial childhood is part of him, because translating from another poem itself provides the distance. Translation is 
not an act of self-effacement or of self-annihilation but an oblique form of self-representation.

This obliqueness is apparent in other poems which are not translations and which are about childhood or about belonging to a people. Mahon will use metaphors to assert there is a distance between himself and his people and then retract this assertion; ${ }^{21}$ or else he will use a metaphor to say there is a relationship between himself and his people only to undo the metaphor. ${ }^{22}$ A second tactic is used when, in writing a poem about a place, redirections are given to other places first: the place is only presented after being displaced. ${ }^{23}$ And a third way of proposing a connection between poet and people while holding these two terms at a distance from each other, is to use a painting (as in 'Courtyards in Delft').

It could be said that translation further develops ideas expressed in other poems where the subject is the relationship of the poet to his people, the Protestants of Northern Ireland. Nerval can act as an alter ego and allow Mahon to present moral ambiguity in an experimental way. This is clear if we examine the translation of 'Antéros' more closely. Here the poem and its translation present two very different scenarios. Nerval's character Antéros is inspired to avenge his wronged ancestors in the war against Jéhovah, his oppressor. Mahon's Anteros seems to have lost sight of the original act of oppression. All that matters is the present struggle. Nerval's Anteros is both active and passive, embodying within himself the attributes of both Cain and Abel. He is marked on the forehead like Cain, and under his white victim's face feels the angry flush of the murderer:

Oui, je suis de ceux-là qu'inspire le Vengeur,

Il m'a marqué le front de sa lèvre irrité,

Sous la pâleur d'Abel, hélas! ensanglantée, J'ai parfois de Cain l'implacable rougeur!

Though he is an innocent victim like Abel, he can sometimes be stung to anger worthy of Cain. Mahon's Anteros is very different - he is not one person but has two separate identities, as the addition of the word 'brother' shows:

Yes, I am one of those revenge inspires

That kissed my forehead with its ulcerous mouth.

I've felt the furious flush of Cain beneath

My murdered brother's blood-commingled tears. 
The translation introduces two new elements: first the idea of a sickness in the body politic, with the 'ulcerous mouth' of revenge, and second, the tears of the victim. The two brothers are now separate entities, joined by the ambiguity of the verb 'feel'. Does the speaker feel anger and grief from the outside, empathizing with his brother, or from within himself? Does he empathize with his brother's urge to kill, or does he want to commit murder because his brother has been killed? The addition of the word 'expropriated' takes the poem from a theological into a political domain. Because the speaker splits into two, each side possessing qualities of Cain and Abel, it is impossible to say who first did the expropriating of the speaker's mother. Brother is pitted against brother in civil war, and each brother alike suffers from a divided mind. The dragon teeth of the conclusion present us with an image of stored-up cycles of violence. The poem thus dramatizes the mentality of the civil war protagonists while showing the integrity of their quarrel.

Many of Mahon's most powerful poems present a speaker who can feel imaginatively, but not morally, at ease among his own people. They represent a supreme balancing act between their own form and the history which goes on outside them. But in 'Anteros' there is a situation where the speaker is neither imaginatively, nor morally, at ease. Translating allows him to relax formal control and to make such statements as: I know what it is like to feel grief with the other, I know what it is like to wish revenge on him.

I have mentioned one of the ways Mahon simplifies Nerval, making his language not mythological but referential. Nerval was at pains to move his poems beyond their historical origins and into a mythological domain. Thus narratives which had a political origin were rewritten by Nerval and gained in mythological significance. Nerval's 'Antéros', like some of his earlier 'élégies nationales', was inspired by contemporary events in Europe - the Greek struggle for independence and the Spanish uprising against Ferdinand VII. ${ }^{24}$ The cry Antéros articulates against Jehovah, 'O tyrannie!', is a reminder of this. In 'Horus', the twin poem to 'Antéros', Nerval deliberately tones down explicit references to Napoleon and to the cult of imperial glory. ${ }^{25}$ In the syncretic sonnets of the Chimeres he creates from personal and collective history, legend, and religion, an extraordinary mythological language. Mahon reverses this process, and uses Nerval's universality in order to refer to poetic and historical preoccupations of his own.

By translating Nerval and using him as his other, or as an alter ego, Mahon can refer to Irish history without being ethnocentric. The Chimeras reveal that what attracts Mahon to translating is not the linguistic, cultural, and historical analysis of the source-text. Indeed, we have seen 
that in simplifying Nerval, Mahon at times appears to resemble the selfeffacing ethnocentric English-speaking translator whose aim is transparency and fluency in the target-text. But on the other hand he deliberately makes his translation read as strange and foreign English. This is in order that he can quote himself into the other, using the other as a trusted friend. He is drawn to translating on ethical grounds because translating ought to be an encounter with something other, rather than an act of appropriation or reduction. The fact that linguistically speaking Mahon does not always do justice to Nerval does not matter for his purposes. As one writer has said in relation to the ethical demands of translation, 'l'essence de la traduction est d'être ouverture, dialogue, métissage, décentrement. Elle est mise en rapport, ou elle n'est rien. ${ }^{26}$ In a poem like 'Anteros' the medium of translation provides sufficient otherness to free Mahon from the problem he presents elsewhere of balancing the work of art against the world to which it refers. It is because versions of culture in Ireland are ethnocentric and mutually exclusive that Mahon needs to translate. Nerval can take him away from his own culture and permit him to comment on it from a necessary distance.

Maynooth University College

\section{Notes}

I. Derek Mahon, The Chimeras (Dublin, 1982). I refer to the version of the Chimères in Gérard de Nerval, Oeuvres, I, edited by Albert Béguin and Jean Richer (Paris, 1974).

2. For a bibliography of translations of the Chimères see Gérard de Nerval, Les Chimeres/The Chimeras: A Version by Peter Fay (London, 1984).

3. See Norma Rinsler, 'Nerval devant la critique anglo-saxonne', Oeuvres et critiques, I3 (1988), 79-84.

4. Andrew Belis [pseud. for Samuel Beckett], 'Recent Irish Poetry', Bookman, 86 (August 1934), 235-6 (p. 235).

5. See Denis Devlin, Collected Poems, edited by J. C. C. Mays (Dublin, 1989); Brian Coffey, Poems and Versions 1929-1990 (Dublin, 1991); Thomas McGreevey, Collected Poems, edited by Susan Schreibman (Dublin and Washington, D.C., I99I); Denis Devlin, Translations into English, edited by Roger Little (Dublin, I992).

6. The Sphere Book of Modern Irish Poetry, edited by Derek Mahon (London, 1972), p. 12.

7. Thomas Kinsella, 'The Irish Writer', in Davis, Mangan, Ferguson?: Tradition and the Irish Writer, edited by Roger McHugh (Dublin, I970), p. 60.

8. See Carson's collection of poems, First Language (Oldcastle, I993).

9. Eugene Nida, Toward a Science of Translating (Leiden, 1964), pp. I59-6r.

Io. Lawrence Venuti, Rethinking Translation (London, I992), p. 5.

II. Venuti, p. 5. 
I2. For this terminology, see Henri Meschonnic, 'Poétique de la traduction', in Pour la poétique II (Paris, 1973), pp. 308, 313-14.

I3. For the idea of the sonnets as 'conjuring acts', see Kurt Schärer, Pour une poétique des Chimères de Nerval (Paris, I98I), p. 26.

14. Julia Kristeva, Soleil noir: dépression et mélancolie (Paris, 1987), p. 167.

15. On mythology as a condensed mode of reference in Nerval, see Jacques Geninasca, Analyse structurale des Chimères de Nerval (Neuchâtel, 197I), pp. I 5-16.

16. See the discussion of Nerval's use of capitals and italics in Léon Cellier, Gérard de Nerval: l'homme et l'oeuvre (Paris, I956), p. 223.

17. On Nerval's punctuation for the spoken voice, see Henri Meschonnic, 'Essai sur la poétique de Nerval', Europe, 516 (I972), 7-30 (p. 21).

I8. In lines 5-6. See also 'Delfica', line 13 ; 'Horus', line 9.

19. Venuti, p. 5 .

20. Version in Derek Mahon, The Hunt by Night (Oxford, I982), pp. 8-9

21. See 'The Spring Vacation', in Mahon, Poems 1962-1978 (Oxford, 1979), p. 4.

22. See 'Derry Morning' and 'Courtyards in Delft', in Mahon, Selected Poems (London and Oldcastle, 1991), pp. 123, 120.

23. See, for example, 'A Lighthouse in Maine', 'A Garage in Co. Cork', 'The Chinese Restaurant in Portrush', and 'Courtyards in Delft' in Selected Poems.

24. For the link between the 'élégies nationales' and the Chimères, see Geninasca (n. 15), pp. 226-7. The latest edition of the early poems is Gérard de Nerval, Oeuvres complètes, edited by Jean Guillaume and Claude Pichois (Paris, I984- ); see, in Vol. 2, 'Ipsara' and 'Chant d'un Espagnol' (pp. 4-8, I I-I2).

25. For a discussion of the political background to 'Horus', see François Constans, Gérard de Nerval devant le destin (Paris, 1979), pp. I87, I9I.

26. Antoine Berman, L'Epreuve de l'étranger: culture et tradition dans l'Allemagne romantique (Paris, 1984), p. I6. 